\title{
Hortensia Pârlog
}

University of Timişoara

Department of English

\section{The Semantics of Heart: Translation Problems}

\section{Summary}

Words hardly ever occur on their own, because they can hardly mean anything on their own; when asked about the meaning of an isolated word, in order to figure it out, what one does is try to place it in a context or use it in a collocation. The verbal contexts in which words appear influence or at least clarify their semantic value; it is because of contextual factors that a word may have more than one meaning. Therefore, the analysis above word level is extremely important. An analysis of translational decisions may also prove to be a valuable source of information in establishing the semantics of a lexical item.

The above statements are illustrated by discussing the semantics of heart. The word occurs in a great number of structures in both English and Romanian, of which eight will be analysed: heart + verb; verb + heart; heart + of phrase; adjective + heart, heart + head noun; head noun + of heart, adjective + preposition + heart; heart in sayings or fixed expressions.

Key words: translation, equivalence, structure (collocation), meaning

\section{Semantika besede heart: težave pri prevajanju}

\section{Povzetek}

Besede redko nastopajo samostojno, ker same po sebi komaj kaj pomenijo. Kadar nas nekdo vpraša po pomenu posamezne besede, jo običajno poskušamo postaviti v sobesedilo oziroma jo uporabimo v kolokaciji. Sobesedila, v katerih se besede uporabljajo, pojasnjujejo ali vplivajo na njihovo semantično vrednost. Prav zaradi dejavnikov sobesedila ima beseda lahko več kot en pomen. Tako je analiza nad besednim nivojem izredno pomembna. Analiza prevodnih odločitev je lahko pomemben vir informacij pri ugotavljanju semantike posamezne leksikalne enote.

Diskusija o semantiki besede heart bo poskušala potrditi zgornje trditve. Tako $\mathrm{v}$ angleščini kot romunšcini se beseda pojavlja $\mathrm{v}$ mnogih strukturah, od katerih jih bomo analizirali osem: heart + glagol; glagol + heart; heart + predložna of zveza; pridevnik + heart, heart + samostalnik; samostalnik + of heart; pridevnik + predlog + heart; heart v pregovorih in stalnih zvezah.

Ključne besede: prevajanje, enakovrednost, struktura (kolokacija), pomen 


\section{The Semantics of Heart: Translation Problems}

\section{Introduction}

In the past fifty years or so, translation scholars have elaborated a lot of different theories on the concept of equivalence, but a universally accepted approach to the notion is still lacking. More than a decade ago, Baker (1992) analyzed the notion of equivalence at different levels, in relation to the translation process, including all different aspects of translation and putting together the linguistic and the communicative approach. She discussed equivalence at word level and above word level, grammatical equivalence, textual and pragmatic equivalence.

Words hardly ever occur on their own, because they can hardly mean anything on their own; when one is asked to give the meaning of an isolated word, one usually tries to place it in a context in order to figure it out. It can, therefore, be assumed that the contexts in which words appear may influence or at least clarify their semantic value, that it is because of contextual factors that a word may have more than one meaning, and that, consequently, the analysis above word level is extremely important. The analysis of translation decisions may also prove to be a valuable source of information in establishing the semantics of the lexical items that combine and form a structure.

\section{The semantics of heart}

I shall illustrate the above statements by discussing the semantics of heart. The word occurs in a great number of structures (collocations, idioms or set expressions) in both English and Romanian, which are often analysable as metaphors or metonymies. The word "structure" is preferred here, because drawing a clear, undisputed line of demarcation between collocations, idioms and set expressions has proved to be difficult and a discussion of these terms is beyond the scope of the present paper. Eight such structures containing the word heart are analysed in what follows, starting from English as the base language: heart + verb, verb + heart, heart + of phrase, adjective + heart, heart + head noun, head noun + of heart, adjective + preposition + heart, and set expressions or idiomatic phrases containing the word heart.

2.1 Heart as an organ in one's chest can be found in four of these structures: heart + verb, adjective + heart, heart + head noun, and head noun + of heart. With one or two exceptions, in all these cases, its Romanian equivalent is inimă ( $<$ Lat. anima).

2.1.1 Heart + verb: e.g., one’s heart beats/ inima bate, ticăie; one’s heart stops/ inima stă, se opreşte; inima încetează să mai bată.

2.1.2 Adjective + heart has the equivalent inimă + adjective in Romanian. The word order differs in the two languages, because, with few exceptions, the usual, neutral position of the 
modifier in the Romanian noun phrase is after the head noun, just as the neutral position of the English modifer is before the head noun: e.g., 0 idee interesanta $=$ an interesting idea. For example, good, healthy, strong heart / inimă bună, sănătoasă; bad, weak heart / inimă slabă, bolnavă; artificial heart / inimă artificială. Sometimes the English adjective may turn into a Romanian prepositional noun phrase (PNP): e.g., human heart / inimă de om.

2.1.3 The heart + head noun structure refers mostly to conditions of the heart, being rather frequent in the medical discourse. In the Romanian equivalent structure, inimă alternates sometimes with another word of Latin origin, cord $(<\operatorname{cor})$, or an adjective derived from it, cardiac, felt to be more scientific terms: e.g., heart attack, failure / atac de inimă, de cord; heart disease, complaint, condition, trouble / boală de inimăa; heart beat / bătaie de inimă, a inimii; heart operation, surgery / operație de inimă, pe cord, intervenție cardiacă; chirurgie cardiacă; heart transplant / transplant de inimă; heart murmur / murmur cardiac. As one can see, in the Romanian translation of these word combinations, the equivalent of the English pre-modifier, heart, becomes a post-modifier, usually expressed by a PNP (the preposition being $d e$, as a rule) or occasionally by a NP in the genitive case (a inimii). The adjective cardiac may also be found in synonymous English collocations (cardiac murmur, cardiac disease).

2.1.4 The structure head noun + of + the heart is formally similar to its Romanian equivalent head noun + de + inimă: e.g., disease, condition of the heart / boală de inimă (for which Romanian also has the more elevated/ scientific alternative afecțiune cardiacă).

2.2 The word heart may be used metaphorically as the seat of feelings and emotions in general or of specific feelings (love, fondness, happiness, sadness, pity, unkindness, fear, etc.). In English, this meaning occurs in six of the eight structures studied: heart + verb, verb + heart, head noun + of heart, adjective + preposition + heart, adjective + heart and in idiomatic phrases.

2.2.1 Examples of structures that refer to feelings in general are pour out/ bare/ open/ uncover/ unlock one's heart / a-şi deschide inima, sufletul ["open one's soul"]; a-şi uşura, descărca inima, sufletul ["relieve one's heart, soul"] (verb + heart); (the) secrets of the heart / secretele inimii (head noun + of the heart); wear one's heart upon one's sleeve / a nu-şi ascunde sentimentele ["not hide one's feelings"], a avea inima deschisă ["have an open heart"] (idiomatic phrase).

2.2.2 The heart + verb structure may suggest feelings of happiness (e.g. one's heart vibrates / a-i tremura inima de fericire ["one's heart trembles with happiness"]), sympathy (e.g., one's heart warms towards sb.; one's heart goes out to sb. I a compătimi din toată inimal din suflet pe cineva ["pity sb. with all one's heart / soul"]), sadness (e.g., one's heart bleeds for sb. / a-i sângera inima; a $i$ se frânge inima ["one's heart breaks"]; a i se rupe sufletul ["one's soul is torn"]; one's heart aches / a-l durea sufletul ["one's soul aches"]), disappointment, dismay (e.g., one's heart sinks / a se dezumfla ["to feel deflated"]; a se potoli ["to calm down"]; a i se strânge inima ["one's heart shrinks"]), excitement, fear or shock (e.g., onés heart leaps, jumps / a-i tresări inima de emotie, de frică, de bucurie ["one's heart is startled by excitement, fear, joy"]). The underlined words 
are adverbials, which contribute to making the meaning of the English structure clearer in Romanian.

2.2.3 The verb + heart structure may also be used for feelings like happiness (e.g. warm, gladden sb.'s heart I a incălzi inima cuiva, a face fericit ["make happy"]), sympathy, pity (e.g., touch sb.'s heart / a-i fi milă ["to pity"]; a trezi sentimente de milă ["arouse feelings of pity, compassion"]; a mişca, a impresiona ["move, impress"]; a atinge coarda sensibilă ["touch the sensitive chord"; "appeal to the emotions"]), sadness (e.g., e.g. sob, cry, weep one's heart out/ a-i seca ochii de atâta plâns ["one's eyes get dry from so much weeping"]; break sb's heart / a frânge inima cuiva; eat (out), devour onés heart/ a suferi în tăcere ["suffer silently"]; take to heart / a pune la suflet), but also unkindness (e.g., not have the heart to / a nu avea inima să; harden sb's heart / a inăspri, a învârtoşa inima cuiva) or love (e.g., steal, capture, win sb.'s heart / a cuceri inima cuiva; lose, give onés heart (to) / a-şi dărui inima cuiva; a îndrăgi ["take to sb.; take a fancy to sb."]).

2.2.4 Love or fondness can also be expressed by the structure head noun + of heart (e.g., a union of hearts / căsătorie bazată pe afecțiune, dragoste ["marriage based on affection, love"]; abundance of heart / prisosul inimii).

2.2.5 Adjective + preposition + heart may denote feelings like love or fondness (e.g., close, dear, near to sb.'s heart / drag ["dear to sb."]; pe gustul cuiva ["to sb.'s taste"]; aproape de sufletul cuiva ["close to sb.'s soul"]), unhappiness and anxiety (e.g., (be) sick at heart / a simți inima grea, o povară pe suflet ["feel a burden on one's soul"]).

2.2.6 Sadness may be expressed with the help of adjectival collocations of the type adjective + heart. e.g., broken, heavy, sore heart / inimă grea, tristă, distrusă; deprimat ["depressed"].

2.2.7 Phrases may also suggest sadness (e.g., have one's heart in one's boots / a fi foarte trist, necăjit, deprimat ["be very sad, downcast, depressed"]; eat one's heart out / a fi foarte trist; $a$ suferi în tăcere ["be very sad"; "suffer in silence"]).

2.3 The word heart may stand for conscience or soul in two of the structural patterns discussed here, which reflects in their translation into Romanian:

2.3.1 Heart + verb: e.g., my heart smote me / simțeam, aveam mustrări de conştiință ["I felt, had pangs of conscience"];

2.3.2 Verb + heart. e.g., search one's/sb's heart / a (-şi) cerceta inima, conştiința ["search one's / sb.'s conscience"]; a privi in inima, in sufletul cuiva ["look into someone's heart/ soul"]; read sb's heart / a citi in inima, sufletul cuiva.

2.4 Attitudes in general or ways of behaviour such as courage, fear/cowardice, enthusiasm, sincerity, honesty are often associated with heart. 
2.4.1 The structures head noun + of heart and adjective + preposition + heart may refer to attitude or behaviour in general: e.g., a change of heart / schimbare de atitudine (usually to a friendlier, more helpful attitude); young at heart / tânăr; comportament tineresc ["youthful behaviour"].

2.4.2 The meaning of heart may be "courage" in:

2.4.2.1 Heart + verb: e.g., my heart fails me / curajul mă părăseşte ["courage leaves me"]; mi se taie picioarele ["my legs give way"].

2.4.2.2 Verb + heart: e.g., give heart to sb./ a încuraja, a sprijini pe cineva ["encourage, support sb."]; have heart / a avea curaj ["have courage"]; keep (up) heart / a nu se pierde cu firea ["not to turn a hair"]; lose heart / a se pierde cu firea, a-şi pierde curajul, a se descuraja ["lose courage, become discouraged"]; pluck up, take heart / a prinde inimă, curaj ["pluck up, take courage"].

2.4.3 In phrases, heart is often associated with cowardice, fear: e.g., his heart is in/ jumps into his mouth / moare de frică ["he is dying of fright"]; i s-a făcut inima cât un purice ["his heart has become as small as a flea"], $i$-a sărit inima din loc ["his heart jumped out of place"]; his heart leaps out of his mouth / este speriat de moarte ["he is scared to death"]; l-au băgat in sperieți ["they frightened him very much"]; have one's heart in one's mouth / a fi grozav de speriat ["be very scared"], a muri de frică ["die of fear"]; a nu mai putea de frică ["be terribly frightened"]).

2.4.4 In two of the structures containing the word heart, the word is used to refer to enthusiasm or its absence:

2.4.4.1 Verb + heart. e.g., put heart into sth. I a face ceva cu tragere de inimă, and

2.4.4.2 Phrases: e.g., his heart is not in it / nu e prea entuziasmat; nu e interesat ["he lacks enthusiasm; he is not interested"].

2.4.5 Sincerity and honesty are suggested by:

2.4.5.1 Head noun + of heart. e.g., the bottom of one's heart / adâncul inimii cuiva;

2.4.5.2. Verb + heart. e.g. cross onés heart / a (se) jura; pe cuvânt ["to swear"; "honestly"];

2.4.5.3 Phrases: e.g., wear one's heart upon one's sleeve / a nu avea gânduri ascunse ["to have no hidden thoughts"]; $\boldsymbol{c e - i}$ in guşă, şi-n căpuşă [approx. "speak one's mind"].

2.5 Heart may refer to someone's personality, disposition or character or may stand for a person that has certain traits of character. This is the case of: 
2.5.1 Heart + of phrase: e.g., a heart of stone, of flint / inimă de piatră; heart of gold / inimă de aur,

2.5.2 Adjective + heart. e.g., good, kind, loving, soft, tender, warm heart / (persoană) cu inimă bună, caldă, iubitoare; cold, cruel, hard / (persoană cu) inimă rece, rea, împietrită; big, generous heart / persoană mărinimoasă; (om cu) suflet mare, generos; faint heart / (persoană) timid(ă), lipsit(ă) de îndrăzneală; brave, stout, valiant heart / inimă vitează; persoană curajoasă, indrăzneață; false heart / inimă nestatornică, trădătoare, falsă; light, free heart / (persoană cu) inima uşoară, nepăsătoare;

2.5.3 Phrases, such as: his heart is in the right place / are intenții bune, frumoase ["he has good intentions"]; este un om bun, săritor ["he is a kind, helpful person"].

2.6 Heart is also used to denote the central, innermost part of something, its main or essential part; this meaning is obvious mainly in the structures:

2.6.1 Heart + of phrase, e.g., the heart of the city, of the capital, of the forest I inima, centrul orasului, capitalei, codrului; the heart of the matter, of the subject, of the debate, of the dilemma, of the mystery / miezul problemei, punctul central al problemei, al subiectului, esenț dezbaterii; the heart of the cabbage, of the vegetable, of a lettuce / inima, miezul, coceanul verzei, miezul legumei, inima salatei;

2.6.2 Verb + heart: e.g., go, get to the heart (of sth.) / a ajunge in miezul, a pătrunde in esența a ceva; lie at the heart (of sth.) I a se afla in miezul a ceva.

2.7 Heart may also serve as a form of address in the structure adjective + heart. e.g., dear, sweet heart / scumpul meu, scumpule, scumpo, dragule, draga mea, iubitule, iubito.

\section{Heart equivalents: Comments}

3.1 Some of the structures discussed here have both a literal and a figurative meaning or an idiomatic meaning, which is reflected in their translation into Romanian; this is revealed only by the context in which they appear. Thus My heart fails me may refer to the organ that no longer perfoms its function: "nu-mi mai bate inima", "îmi stă inima" (literal meaning) or it may suggests lack of courage: "curajul mă părăseşte"; similarly, My heart aches may have a literal meaning, "mă doare inima", and a metaphorical one, suggesting sadness: "mă doare sufletul", "mi se rupe inima (de durere)".

3.2 Sometimes the meaning is dictated by the way in which the word heart collocates not only lexically, but also grammatically (an aspect that this paper does not tackle). An example is offered by have heart (zero article; the metaphorical meaning is "courage"); have a heart (indefinite article; the metaphorical meaning changes to "pity", "kindness"); have a heart for [sth.] (indefinite article, preposition; the metaphorical meaning is "inclination", "liking"); 
(not) have the heart to (do sth) (definite article, long infinitive; the metaphorical meaning is "unkindness").

3.3 Some of the structures can be found in both the source and the target language; they roughly convey the same meaning in the two languages, and consist of equivalent lexical items (possibly with a difference in word order): e.g., the heart beats / inima bate (heart /inimă + verb; the noun denotes the organ); a heart of gold / inimă de aur (heart /inimă + preposition + noun; the structure is used to refer to someone's disposition, character); healthy heart / inimă sănătoasă (adjective + heart / inimă + adjective ).

It is, however, possible that in spite of structural similarity the meaning of the source language structure is misunderstood in the target language, particularly if it is figurative: e.g. (he is) sick at heart (adjective + preposition + heart, figurative meaning, "he feels great disappointment, fear or grief, i.e. he is unhappy") does not mean *(el este) bolnav de inimă (adjective + preposition + inimă; literal meaning, "he has heart trouble").

3.4 Heart is translated as inimă or cord whenever the word denotes the organ. The structures in the two languages may not be identical: thus, the English heart + head noun usually becomes head noun + PNP in Romanian: e.g., heart attack / atac de cord, de inimă).

3.5 The Romanian word inimă has many of the figurative meanings that the English heart does, so the word is often used in the translation of structures that have such meanings. However, it is also possible that, even in the case of structural and semantic similarity, other Romanian equivalents of the word are used.

Here is a synthesis of the main Romanian equivalents of the English heart.

3.5.1. The word may be translated as an abstract noun:

- Suflet ("soul"), e.g to unburden one's heart / a-şi descărca sufletul; put heart in / a pune suflet in ;

- Conştiință ("conscience"), e.g., my heart smote me / aveam mustrări de conștiintăă;

- Curaj, indrăzneală ("courage", "daring”), e.g., to lose heart I a-şi pierde curajul; faint heart I lipsit de îndrăzneală;

- Gând ("thought"), e.g., to set one's heart on / a-şi pune in gând;

- Milă ("pity"), e.g., have a heart / ai milă;

- Inclinație ("inclination", "call”, "vocation"): e.g., follow one’s heart / a-şi urma propriile inclinatiii;

- Gust, interes ("taste", "liking", "interest”): e.g., close, dear to sb's heart / pe gustul cuiva, de interes pentru cineva;

- Atitudine ("attitude"): e.g., a change of heart / o schimbare de atitudine;

- Mijloc, centru, miez, esență ("middle", "centre", "core", "essence"): e.g., the heart of the forest I mijlocul pădurii; the heart of the problem / esenta problemei; 
3.5.2 When heart is used as a term of address suggesting love, Romanian resorts to substantivized adjectives: dear, sweet heart / scumpule, scumpo, dragule, dragul meu, dragă, draga mea, etc.

3.5.3 The English structure may be translated by a structure, usually an idiomatic phrase, a saying, containing a noun denoting another part of the body, such as the eyes, e.g. sob, cry, weep one's heart out / a-i seca ochii de atâta plâns; the legs, e.g., my heart fails me / mi se taie picioarele (de frică); the breast/ chest, e.g., press to one's heart / a strânge la piept; or stomach, e,g, heart burn / arsuri la stomac.

3.5.4 The equivalent of heart or of the whole structure containing the word heart may be an adjective: e.g., heart surgery / chirurgue cardiacă; have a heart / fii milos ["be compassionate"]; his heart is in his boots / este necăjit, foarte trist, deprimat ["he is upset, very sad, depressed"]; his heart is not in it I nu e prea entuziasmat; nu e interesat ["he is not too enthusiastic; he is not interested"]; heavy heart / trist, deprimat ["sad, depressed"]. Sometimes not only is heart omitted in the translation, but the Romanian adjective corresponds in fact to the other term of the collocation: e.g., gladden the heart / a face fericit ("make happy"); dear to sb's heart / drag (cuiva) ("dear").

3.5.5 The word heart may be omitted in the translation and the equivalent of the whole structure may be a verb, denoting the feeling or attitude suggested by heart. e.g., touch sb's heart / a impresiona, a misca (pe cineva) [“impress, move sb."]; give heart to sb. I a incuraja, a sprijini ["encourage, support"]; cross onés heart / a (se) jura ["swear"]; onés heart sinks / a se dezumfla, a se potoli.

3.6 The English verbs that collocate with the noun heart may have semantic features not present in the Romanian verbs, e.g. they may also suggest the manner, the duration or the cause of the action performed or suffered by the heart. Such features are rendered into Romanian with the help of adverbials. The adverbial either replaces the word heart (e.g., set one's heart on sth I a-şi dori ceva foarte mult ["want sth. very much"]) or simply clarifies the meaning of the whole English structure: e.g., one's heart vibrates / a-i tremura inima de emotie, de fericire (cause or reason of the action) ["one's heart trembles with emotion, with happiness"]; one's heart sinks / inima se strânge de tristete (cause or reason of the action) ["one's heart shrinks because of sadness"]; sob, cry, weep one's heart outl a-i seca ochii de atâta plâns (cause or reason of the action) ["one's eyes get dry from so much crying"]; one's heart throbs, thumps, is thudding, pounds, palpitates/ inima bate tare, cu putere (manner of the action) ["one's heart beats strongly"], palpită, zvâcneşte; one's heart gallops/ inima bate cu repeziciunel repede (manner of the action) ["one's heart beats rapidly"]; one's heart quickens, becomes fast/ inima incepe să bată repede (manner of the action) ["one's heart begins to beat faster/quicker"]; one's heart skips, misses a beat/ inima se opreşte $\underline{o}$ secundălo clipă (duration of the action) ["one's heart stops for a second/ moment"].

3.7 Most English idiomatic expressions correspond to Romanian idiomatic expressions, which may or may not contain the equivalent word of heart (inimă): e.g., his heart is in, jumped into 
his mouth / i se face inima cât un purice; $i$-a sărit inima din loc; his heart leaps out of his mouth I este speriat de moarte; l-au băgat în sperieți; wear one’s heart upon one's sleeve / ce e-n gușă şi-n căpuşă.

3.8 Sometimes the Romanian equivalent is simply an explanation, a paraphrase of the English structure: e.g., a union of hearts / căsătorie bazată pe afecțiune, pe dragoste ["marriage based on affection, on love"].

\section{Conclusion}

The meanings of the word heart are very important for its translation, and they are determined, most frequently, by the structures in which the word occurs; on the other hand, the translation of the word is important for the learner's understanding or clarifying its meaning, even if sometimes this may involve either some loss or some addition of meaning (particularly when heart is used figuratively). The word and some of the structures in which it occurs may be given a literal translation, because the source and the target language words are referentially equivalent; when they are just connotatively equivalent, Romanian makes use of a variety of words that correspond to the meanings of heart or, sometimes, uses a structure in which the word is omitted altogether. There are also many instances when the word heart and the structure in which it occurs undergo a change of grammar - a translation procedure known as shift (Catford 1965) or transposition (Vinay and Darbelnet 1958). Thus, sometimes the Romanian translation employs structure shifts (e.g., a change of word order) or class shifts (e.g., the equivalent of the noun heart is a different part of speech in the target language).

\section{Bibliography}

Baker, M. 1992. In Other Words. A Coursebook on Translation. London: Routledge.

Catford, J.C. 1965. A Linguistic Theory of Translation. London: Oxford University Press.

Vinay, J.P., and J. Darbelnet. 1958. Stylistique comparée du français et de l'anglais. Méthode de traduction. Paris: Didier. 